\title{
A novel coenzyme- $Q$ approach for the prevention of postsurgical adhesion
}

\author{
Ramazan Kuşaslan $^{1}$ (D), Gülçin Ercan ${ }^{1}$ (D), Orhan Ağcaoğlu²(D), Serdar Altınay ${ }^{3}$ (D), Sinan Binboğa ${ }^{1}$ (D), Yüksel Altınel (iD) \\ ${ }^{1}$ Department of General Surgery, Bagcilar Training and Research Hospital, Istanbul, Turkey \\ 2 Department of General Surgery, Koc University School of Medicine Hospital, Istanbul, Turkey \\ ${ }^{3}$ Department of Pathology, Bagcilar Training and Research Hospital, Istanbul, Turkey
}

\begin{abstract}
Objective: Postoperative intraperitoneal adhesions are an unsolved and important problem in abdominal surgery. In the present study, the probable preventive role of coenzyme-Q in the development of peritoneal adhesions was investigated.

Material and Methods: Sixteen Wistar Hannover male rats weighing 300-350 g were randomly separated into two groups of 8 rats each. The cecum was abraded with a sterile gauze until sub-serosal hemorrhage developed. A patch of peritoneum located opposite to the cecal abrasion was completely dissected. No treatment was given to Group 1 . Group 2 received $30 \mathrm{mg} / \mathrm{kg}$ coenzyme- $Q$, which was injected $2 \mathrm{~mL}$ intraperitoneally. All the rats were sacrificed on the postoperative $21^{\text {st }}$ day, and after adhesions were scored macroscopically, tissue specimens of the peritoneum and bowel were subjected to histopathological investigation. Tissue and blood specimens were also taken for biochemical analysis to investigate antioxidant efficiency. Results: Adhesion scores were significantly different between the control group and the coenzyme-Q group ( $p=0.001)$. According to the tissue levels of GSH-Px, MDA, and SOD levels, there was no significant difference between the study groups $(p=0.074, p=0.208, p=0.526)$. According to the plasma GSH-Px and SOD levels, there was significant difference between the groups $(p=0.002, p=0.001)$, but the difference was not significant at MDA levels ( $p=0.793$ ). The differences between the pathological scores of the control and coenzyme- $Q$ ( $p=0.028$ for fibrosis; $p=0.025$ for inflammation) groups were statistically significant.
\end{abstract}

Conclusion: This study confirms that coenzyme-Q is the potential application in the prevention of early postoperative adhesions.

Keywords: Coenzyme Q, adhesion, surgery

Cite this article as: Kuşaslan R, Ercan G, Ağcaoğlu O, Altınay S, Binboğa S, Altınel Y. A novel coenzyme-Q approach for the prevention of postsurgical adhesion. Turk J Surg 2020; 36 (2): 202-208

\section{Corresponding Author}

Yüksel Altınel

E-mail: dryukselaltinel@hotmail.com

Received: 13.05.2019

Accepted: 30.12 .2019

Available Online Date: 08.06 .2020

(- Copyright 2020 by Turkish Surgical Society Available online at www.turkjsurg.com

DOI: $10.5578 /$ turkjsurg.4398

\section{INTRODUCTION}

Peritoneal adhesions are bands of fibrous tissue connecting the abdominal organs to the abdominal wall or each other. Adhesions emerge quickly after the damage to the peritoneum due to surgery, such as trauma, irradiation, or infection (1). Abdominal adhesions are one of the main reasons for postsurgical morbidity and mortality and besides, the incidence rises up to $97 \%$ after gynecological and general surgical abdominal operations in the literature (2). The importance of postoperative adhesion formation has become a significant burden socioeconomically (3). Different substances and techniques are used to solve the problem, but unfortunately, an effective solution has not yet been accomplished (4).

Coenzyme-Q-10 is a fat-soluble, vitamin-like compound naturally found in most tissues of the human body that is also a fundamental ingredient for life and health of every living cell, and furthermore, this endogenous cellular antioxidant is a safe and effective therapeutic antioxidant $(5,6)$.

Based on the antioxidant property of coenzyme-Q-10, we aimed to evaluate its beneficial effects to determine the anti-inflammatory process among the experimental postoperative intraabdominal adhesions. We hypothesized that coenzyme-Q-10 is helpful to improve the unmet needs of the consequences of oxidative stress. We considered that we can put a value to the process of intraabdominal adhesion formation. 


\section{MATERIAL and METHODS}

Consent was received from the Bagcilar Training and Research Hospital Experimental Animals Production and Research Laboratory Ethical Committee (HADYEK/2013-02/28.01.2013). Sixteen Wistar Hannover male rats (average weight: 300-350 g, age: 6-7 months) were housed individually in wire cages under constant temperature $\left(21 \pm 2^{\circ} \mathrm{C}\right)$ with a 12-hour light-dark cycle. The animals were allowed free access to water and standard rat chow. Twelve hours before anesthesia, animals were deprived of food but had free access to water until 2 hours before anesthesia. No enteral or parenteral antibiotics were administered during the study.

All rats were sacrificed with high-dose prolonged diethyl ether inhalation (minimum 10 min.) on postoperative day 21.

\section{Study Groups and Surgical Procedure}

The rats were randomly divided into two groups of eight animals each. All animals were anesthetized by intramuscular injection of $30 \mathrm{mg} / \mathrm{kg}$ ketamine hydrochloride (Ketalar, Parke-Davis, Istanbul) and $5 \mathrm{mg} / \mathrm{kg}$ xylazine (Rompun, Bayer, Istanbul). The abdomen was shaved and prepared with povidone-iodine. Under sterile conditions, a midline laparotomy was performed. The cecum was abraded with sterile gauze until sub-serosal hemorrhage developed. A $1 \times 1 \mathrm{~cm}$ patch of the peritoneum located opposite to the cecal abrasion was completely dissected. In Group 1 (control group), adhesion induction was performed and no treatment was given. In Group 2 (coenzyme-Q-10 group), after adhesion induction, 30 mg/kg coenzyme-Q-10 was injected 2 $\mathrm{mL}$ intraperitoneally. Animals were allowed access to food and water after the operation. All operations were performed by the same surgeon. Rats were sacrificed on the postoperative $21^{\text {st }}$ day.

Adhesions were classified by a surgeon who was unaware of the groups according to a diamond adhesion scoring system based on the evaluation of the appearance, extent, and strength of the adhesions (Table 1) (7).

\section{Evaluation of Oxidative Stress}

Postmortem liver samples were taken and kept on an ice bath until homogenization. The tissues were homogenized in serum physiologic solution (20 wt/vol), then centrifuged at $4000 \mathrm{~g}$ for 15 minutes (min), and upper clear supernatants were used in the assays. All the procedures were performed at $4^{\circ} \mathrm{C}$ throughout the experiments. Protein level of the clear supernatants was studied by the biuret method. Oxidative stress makers were measured as following; Malondialdehyde (MDA) levels ( $\mathrm{nmol} / \mathrm{g})$, glutathione-peroxidase (GSH-Px) (U/g) and superoxide dismutase (SOD) $(\mathrm{U} / \mathrm{g})$ levels by micro ELISA method. All Elisa kits were purchased from EIAab Science Co. Ltd. All plates were read on $450 \mathrm{~nm}$ wavelength in DAR800 ELISA reader (8-10).

\section{Histopathological Evaluation}

Histopathological analyses were carried out in the Pathology Department of Bağcılar Training and Research Hospital. Histopathological examination was performed by using light microscopic (Olympus BX51) analyses. The samples obtained from the abraded cecal tissue and the adjacent peritoneal tissue were fixed in 10\% neutral buffered formalin solution for two days. Tissues were washed in running water and were dehydrated with increasing concentrations of ethanol. After dehydration, specimens were placed into xylene to obtain transparency and embedded in paraffin. Embedded tissues were cut into $5 \mu \mathrm{m}$ thick sections and were stained with hematoxylin and eosin and trichrome. Histopathologic examinations were performed by a pathologist blinded to the study groups. The samples stained with hematoxylin and eosin were examined for inflammation, and the presence of fibrosis was evaluated in the hematoxylin/ eosin- and trichrome-stained samples using a semi-quantitative scoring system (Table 2, 3) (11,12).

Table 1. Adhesion scoring system

\begin{tabular}{|c|c|c|c|}
\hline Score & Extent & Appearance & Strength \\
\hline 0 & No & No & No \\
\hline 1 & $<25 \%$ & Filmy, avascular & Separated easily \\
\hline 2 & $25-50 \%$ & Dense, avascular & Separated by traction \\
\hline 3 & $50-75 \%$ & Dense, capillary vascularization & Sharp dissection needed for separation \\
\hline 4 & $>75 \%$ & Dense, vascular & Sharp dissection needed for separation \\
\hline
\end{tabular}

Table 2. Scoring system for inflammation

0: No inflammation

1: Giant cells, lymphocytes, and plasma cells

2: Giant cells, plasma cells, eosinophils, and neutrophils

3: Inflammatory cell infiltration and micro-abscess formation
Table 3. Scoring system for fibrosis

0 : No fibrosis

1: Mild

2: Moderate

3: Severe 


\section{Statistical Analyses}

Data analysis was performed using NCSS (Number Cruncher Statistical System) 2007 Statistical Software (Utah, USA) program. The differences among the groups were evaluated by Mann-Whitney-U and Chi-square tests, as appropriate. Statistical significance was defined as $p<0.05$.

\section{RESULTS}

\section{Adhesion Scores}

Adhesion scores of the groups and statistical evaluation are shown in Table 4. There was a significant difference between the control group and the coenzyme-Q group $(p=0.001)$.

\section{Oxidative Stress}

The tissue levels of GSH-Px, malondialdehyde (MDA), and superoxide dismutase (SOD) levels are shown in Table 5. According to the GSH-Px, MDA, and SOD levels, there were no significant differences between the study groups ( $p=0.074, p=0.208, p=0.526$ ).

Mean plasma GSH-Px, MDA, and superoxide dismutase (SOD) levels of the groups are shown in Table 6. According to the GSHPx and SOD levels, there was a significant difference between the groups ( $p=0.002, p=0.001)$, but the difference was not significant at the MDA levels $(p=0.793)$.

\section{Histopathological Results}

Histological images of the pathological scores are shown in figures $A$ and $B$. The pathological scores for fibrosis and inflammation are summarized in Tables 7 and 8, and mean pathological scores of the groups are given in Table 9. The differences between the control and coenzyme-Q $(p=0.028$ for fibrosis; $p=$ 0.025 for inflammation) groups were statistically significant.

\section{DISCUSSION}

Abdominal adhesions are bands of fibrous tissue that can form between abdominal tissues and organs. Abdominal adhesions cause tissues and organs in the abdominal cavity to stick together $(12,13)$. During the normal peritoneal healing period, the balance between fibrin deposition and degradation are crucial for adhesion formation, and the main reason of an intraperitoneal adhesion is mostly considered to be the result of a surgical trauma to the mesothelium and peritoneum which initiates an inflammatory response, followed by release of fibrin-rich exudates and the formation of fibrinous adhesion (13).

Regarding the mechanism of adhesion formation, fibrinolysis and extracellular matrix remodeling, including cell proliferation, migration, differentiation, angiogenesis, and apoptosis, are critical for the regulation of the adhesive process as controlling inflammation at initial stages $(7,13,14)$.

Current up to date studies have reported three main methods for preventing the formation of postoperative adhesions, including reduction of peritoneal trauma by using minimally invasive surgical procedures, such as laparoscopic and robotic surgery; prevention of fibrin formation with pharmacological agents, such as tissue plasminogen activators; and reducing contact between organs and intra-abdominal structures by using barrier methods; however, no single approach or management has been totally satisfactory in reducing the risk of adhesion formation $(15,16)$.

Typically, the expression of adhesion density starts with thin line filmy adhesion which is usually taken down easily by blunt dissection, progressing structure where sharp dissection or energy devices are required and finally firmly adherent, where no surgical anatomical plane is clear (17).

\begin{tabular}{|l|c|c|}
\hline Table 4. Mean adhesion scores of the groups & \multicolumn{2}{|c|}{$\mathbf{p}$} \\
\hline Groups & Mean adhesion scores & $\mathbf{0 . 0 0 1}$ \\
\hline Control & $3.63 \pm 0.52$ & \\
\hline Coenzyme-Q & $1.38 \pm 0.92$ & \\
\hline
\end{tabular}

Table 5. Tissue antioxidant levels of the groups

\begin{tabular}{|l|c|c|c|}
\hline & Control & Coenzyme-Q & p \\
\hline GSH-Px & $4208.05 \pm 1248.11$ & $3081.86 \pm 917.3$ & 0.074 \\
\hline SOD & $0.17 \pm 0.03$ & $0.16 \pm 0.02$ & 0.526 \\
\hline MDA & $1.96 \pm 2.17$ & $2.55 \pm 0.93$ & 0.208 \\
\hline
\end{tabular}

Table 6. Plasma antioxidant levels of the groups

\begin{tabular}{|l|c|c|c|}
\hline & Control & Coenzyme-Q & p \\
\hline GSH-Px & $0.94 \pm 0.15$ & $0.53 \pm 0.2$ & $\mathbf{0 . 0 0 2}$ \\
\hline SOD & $170.13 \pm 20.58$ & $100.37 \pm 21.73$ & $\mathbf{0 . 0 0 1}$ \\
\hline MDA & $3.6 \pm 0.55$ & $3.75 \pm 1.19$ & 0.793 \\
\hline
\end{tabular}



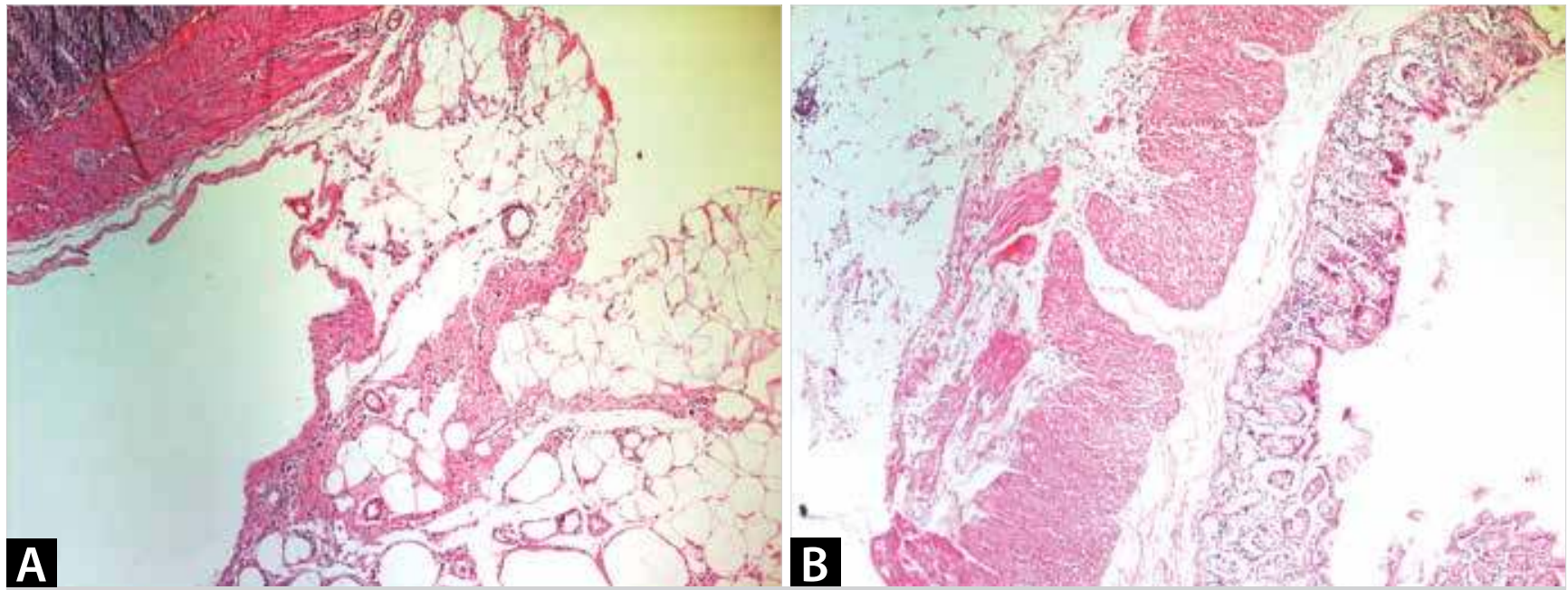

Figure 1. Histopathologic and histochemical findings. (A. HE; $\times 100)$; this picture shows prominent inflammation (score 2). Upper left: Colonic mucosa. (B. HE; x100); decreased inflammation and fibrosis seen in the coenzyme-Q group.

Table 7. Pathological scores for fibrosis

\begin{tabular}{|l|c|c|c|c|}
\hline & Score-0 & Score-1 & Score-2 & Score-3 \\
\hline Control $(n=8)$ & 0 & 2 & 5 & 1 \\
\hline Coenzyme-Q $(n=8)$ & 3 & 4 & 1 & 0 \\
\hline
\end{tabular}

Table 8. Pathological scores for inflammation

\begin{tabular}{|l|c|c|c|c|}
\hline & Score-0 & Score-1 & Score-2 & Score-3 \\
\hline Control $(n=8)$ & 0 & 1 & 6 & 1 \\
\hline Coenzyme-Q $(n=8)$ & 3 & 4 & 1 & 0 \\
\hline
\end{tabular}

Table 9. Mean pathological scores of the groups

\begin{tabular}{|l|c|c|c|}
\hline & Control & Coenzyme-Q & p \\
\hline Fibrosis & $1.9 \pm 0.6$ & $0.8 \pm 0.7$ & $\mathbf{0 . 0 2 8}$ \\
\hline Inflammation & $2 \pm 0.5$ & $0.8 \pm 0.7$ & $\mathbf{0 . 0 2 5}$ \\
\hline
\end{tabular}

There are reports regarding adhesion incidence following surgical operations as high as 95\% (18); however, advances in surgical technology and techniques, such as minimal invasive ones as robotics, can help to minimize the risk of adhesion formation. Moreover, patients undergoing surgery for peritoneal adhesions have increased risk for morbidities due to repeat operations including, anastomotic leakage, enterocutaneous fistulas, small bowel obstructions, and infertility $(19,20)$.

On the other hand, due to re-operations, morbidities and complexity of these operations, cost effectivity is one of the important issues for the management for adhesions. Arung et al. have noted the annual estimated economic impact of peritoneal adhesions about $\$ 1.3$ billion (21) in the USA, and in another study, Ray et al. have reported that the approximate costs associated with sur- gical procedures regarding adhesion management exceeded \$2 billion without the loss of productivity (22).

Over recent decades, various efforts have been taken against the pathogenesis of adhesion formation. As far we know, the key step of preventing adhesions is the reconstruction of the neo-mesothelial cell layer which requires approximately 5-8 days for parietal peritoneum and visceral mesothelium. During these stages, avoiding fibrinous adhesion formation, preventing the invasion of fibroblasts, and promoting remesothelialization play critical roles in adhesion prophylaxis. When we analyzed the literature, some studies recommend using physical barrier systems to separate injured tissue surfaces during the first few postoperative days $(23,24)$. Barrier systems, including solutions, solid sheets, and in-situ cross-linkable hydrogels are all designed 
to reduce the contact between adjacent organs. However, there are cons and pros for every technique as hydrogels applied to the prevention of adhesion have good results, but relatively long gelation time or requirement of UV illumination may be impractical (25). Furthermore, another anti-adhesion method, Seprafilm, is difficult to place in the peritoneal cavity, and after becoming wet, it is difficult to move to the correct position. On the other hand, in recent years, many proteolytic enzymes have been used as anti-adhesive agents including, trypsin, papain, hyaluronidase, streptokinase, and streptodornase (26). The use of fibrinolytic agents that prevent fibrin accumulation has displayed anti-adhesive features, but on the contrary, they have triggered hemostasis problems and degeneration of wound healing (27). In addition to these anti-adhesion techniques, Cakir et al. have reported the use of an enzyme preparation of Clostridium histolyticum that contains collagenases, which are the only proteolytic enzymes that can break up active collagens (28). As mentioned in their study, collagenase removes necrotic tissues, which stick to the wound surface by collagen fibers and prevent wound healing through an enzymatic method. The result of their study was the same as the literature, showing less adhesion and better healing of the peritoneal defect.

Up to date, we know that an ideal method should not only be anti-adhesive, resorbable, and easily applicable with minimally invasive techniques as laparoscopy, but should also adhere to traumatized surfaces without suture or staples, or even oozing surfaces. Compared to other methods, Takagi et al. have developed a powdered anti-adhesion material to resolve these issues (29) In this study, they have noted two main advantages of powder compared with the sheet and liquid materials. First, a powder can be administered in both open and laparoscopic surgery settings, and second, only a minimal dose is necessary because it is easy to administer the powder locally at the desired site to prevent adhesion formation.

Regarding all of these anti-adhesion methods, we used a different technique to manage the collagen synthesis and fibroblast stage of adhesion formation. In wound healing process, the production of reactive oxygen species is vital; however, exposure to excessive reactive oxygen species also induces oxidative stress and impairs wound healing (30).

Coenzyme-Q-10 is an effective fat-soluble antioxidant and essential element of the mitochondrial respiratory chain and a safe material with very low toxicity $(31,32)$. In a recent study, Yoneda et al. have reported that topical application of the reduced form of coenzyme-Q-10 decreased inflammatory reactions in the granulation stage during the wound healing period (33). By using Coenzyme-Q-10 in liquid form intraperitoneally, we determined a significant decrease of fibrosis and inflammation between the study groups.
However, compared to other techniques in the literature, our experimental model evaluated oxidative stress, adhesion and biomarkers in a different way $(34,35)$. We measured the diamond adhesion score and investigated that clinical adhesion formation get decrease by the effect of coenzyme-Q-10 and we also obtained promising results of GSH-Px and SOD regarding anti-oxidant and anti-inflammatory process for pathological adhesion formation, we saw that utilization of coenzyme-Q-10 could be beneficial for intraabdominal protection after surgical procedures.

\section{CONCLUSION}

Our study has a potential contribution to reduce postoperative adhesions and apparently showed equivalent efficacy to other available anti-adhesion techniques and materials. We believe that coenzyme-Q-10 can be a good anti-adhesive agent with feasibility, non-toxicity, and effectiveness. Especially, more detailed experimental and clinical large studies are required to test laparoscopic or robotic procedures.

Ethics Committee Approval: Consent was received from the Bağcılar Education and Research Hospital Experimental Animals Production and Research Laboratory Ethical Committee (HADYEK/2013-02/28.01.2013).

Informed Consent: Informed consent form was obtained from all patients.

Peer-review: Externally peer-reviewed.

Author Contributions: Concept - R.K.; Design - R.K., S.A.; Supervision - R.K.; Resource - S.A., O.A.; Materials - G.E., S.A.; Data Collection and/or Pro-cessing - S.B., O.A.; Analysis and Interpretation - O.A., G.E.; Literature Review - S.B., Y.A., G.E.; Writing Manuscript - R.K., S.B. Y.A.; Critical Reviews - Y.A.

Conflict of Interest: The authors have no conflicts of interest.

Financial Disclosure: Financial support was provided by departmental sources.

\section{REFERENCES}

1. Sulaiman H, Gabella G, Davis C, Mutsaers SE, Boulos P, Laurent GJ, et al. Presence and distribution of sensory nerve fibers in human peritoneal adhesions. Ann Surg 2001; 234:256-61. [CrossRef]

2. Yang B, Gong CY, Zhao X. Preventing postoperative abdominal adhesions in a rat model with PEG-PCL-PEG hydrogel. Intern J Nanomed 2012; 7: 547-57. [CrossRef]

3. Attard JAP, MacLean AR. Adhesive small bowel obstruction: epidemiology, biology and preventio. Can J Surg 2007; 50: 4. [CrossRef]

4. Aysan E, Basak F, Kinaci E. Experimental adhesion model: effect of viscosities of fluids put in the peritoneal cavity on preventing on peritoneal adhesions. Exp Anim 2007; 56: 349-54. [CrossRef]

5. Turunen M, Olssen J, Dallner JG. Metabolism and function of coenzyme Q J Biochim Biophys Acta 2004; 1660: 171-99. [CrossRef]

6. Hidaka T, Fuji K, Funahashi I, Fukutomi N, Hoseo K. Safety assessment of coenzyme Q10 (CoQ10). J Biofactors 2008; 32: 199-208. [CrossRef] 
7. Altinel Y, Chung SS, Okay G, Uğraş N, Işık AF, Öztürk E, et al. Effect of chitosan coating on surgical sutures to strengthen the colonic anastomosis. Ulus Travma Acil Cerrahi Derg 2018; 24: 405-11. [CrossRef]

8. Schramm DD, Karim M, Schrader HR, et al. Honey with high levels of antioxidants can provide protection to healthy human subjects. J Agric Food Chem 2003; 51: 1732-5. [CrossRef]

9. Gheldof N, Wang XH, Engeseth NJ. Buckwheat honey increases serum antioxidant capacity in humans. J Agric Food Chem 2003; 51: 1500-5. [CrossRef]

10. Enechukwu CI, Onuegbu AJ, Olisekodiaka MJ, Eleje GU, Ikechebelu JI, Ugboaja JO, et al. Oxidative stress markers and lipid profiles of patients with polycystic ovary syndrome in a Nigerian tertiary hospital. J Obstet Gynecol Sci 2019; 62: 335-43. [CrossRef]

11. Watanabe K, Shinmoto H, Kobori M, et al. Stimulation of cell growth in the U-937 human myeloid cell line by honey royal jelly protein. $J$ Cytotechnology 1998; 26:23-7. [CrossRef]

12. Bothin C, Okada M, Midtvedt T, Perbeck L. The intestinal flora influences adhesion formation around surgical anastomoses. Br J Surg 2001; 88: 143-5. [CrossRef]

13. Cheong YC, Laird SM, Li TC, Shelton JB, Ledger WL, Cooke ID. Peritoneal healing and adhesion formation/reformation. J Hum Reprod Update 2001; 7: 556-66. [CrossRef]

14. Altınel Y, Taspinar E, Özgüç H, Öztürk E, Akyıldız EÜ, Bagdas D. The protective effect of ClinOleic against post-surgical adhesions. Ulus Travma Acil Cerr Derg 2014; 20: 1-6. [CrossRef]

15. Tingstedt $B$, Isaksson K, Andersson E, Andersson R. Prevention of abdominal adhesions--present state and what's beyond the horizon? Eur Surg Res 2007; 39: 259-68. [CrossRef]

16. Lauder Cl, Garcea G, Strickland A, Maddern GJ. Abdominal adhesion prevention: still a sticky subject? J Dig Surg 2010;27:347-58. [CrossRef]

17. De laco PA, Stefanetti M, Pressato D, Piana S, Dona M, Pavesio A, et al. A novel hyaluronan-based gel in laparoscopic adhesion prevention: preclinical evaluation in an animal model. Fertil Steril 1998; 69: 31823. [CrossRef]

18. Menzies $D$, Ellis $H$. Intestinal obstruction from adhesions--how big is the problem? Ann R Coll Surg Engl 1990; 72: 60-3. [CrossRef]

19. Parker MC, Wilson MS, Menzies D, Sunderland G, Thompson JN, Clark DN, et al.; Surgical and Clinical Adhesions Research (SCAR) Group. Colorectal surgery: the risk and burden of adhesion-related complications. Colorectal Dis 2004; 6: 506-11. [CrossRef]

20. Boland GM, Weigel RJ. Formation and prevention of postoperative abdominal adhesions. J Surg Res 2006; 132: 3-12. [CrossRef]

21. Ray NF, Denton WG, Thamer M, Henderson SC, Perry S. Abdominal adhesiolysis: in patient care and expenditures in the United States in 1994. J Am Coll Surg 1998; 186: 1-9. [CrossRef]

22. Ray NF, Larsen JW Jr, Stillman RJ, Jacobs RJ. Economic impact of hospitalizations for lower abdominal adhesiolysis in the United States in 1988. Surg Gynecol Obstet 1993; 176: 271-6. [CrossRef]
23. Becker JM, Dayton MT, Fazio VW, Beck DE, Stryker SJ, Wexner SD, et al. Prevention of postoperative abdominal adhesions by a sodium hyaluronate-based bioresorbable membrane: a prospective, randomized, double-blind multicenter study. J Am Coll Surg 1996; 183: 297-306. [CrossRef]

24. Marana R, Catalano GF, Caruana P, Margutti F, Muzii L, Mancuso S. Postoperative adhesion formation and reproductive outcome using Interceed after ovarian surgery: a randomized trial in the rabbit model. Hum Reprod 1997; 12: 1935-8. [CrossRef]

25. Sawhney AS, Pathak CP, van Rensburg JJ, Dunn RC, Hubbell JA. Optimization of photopolymerized bioerodible hydrogel properties for adhesion prevention. J Biomed Mater Res 1994; 28: 831-8. [CrossRef]

26. Larsson B, Lalos O, Marsk L, Tronstad SE, Bygdeman M, Pehrson S, et al. Effect of intraperitoneal instillation of $32 \%$ dextran 70 on postoperative adhesion formation after tubal surgery. Acta Obstet Gynecol Scand 1985; 64: 437-41. [CrossRef]

27. Yagmurlu A, Barlas M, Gursel I, Gokcora IH. Reduction of surgery-induced peritoneal adhesions by continuous release of streptokinase from a drug delivery system. Eur Surg Res 2003; 35: 46-9. [CrossRef]

28. Cakir M, Tekin A, Kucukkartallar T, Yılmaz H, Belviranlı M, Kartal A. Effectiveness of collagenase in preventing postoperative intra-abdominal adhesions. Int J Surg 2013; 11: 487-91. [CrossRef]

29. Takagi K, Araki M, Fukuoka H, Takeshita H, Hidaka S, Nanashima A, et al. Novel powdered anti-adhesion material: preventing postoperative intra-abdominal adhesions in a rat model. Int J Med Sci 2013; 10:46774. [CrossRef]

30. Sarsour EH, Kumar MG, Chaudhuri L, Kalen AL, Goswami PC. Redox control of the cell cycle in health and disease. Antioxid Redox Signal 2009; 11:2985-3011. [CrossRef]

31. Ramirez-Tortosa MC, Ramirez-Tortosa CL, Mesa MD, Granados S, Gil A, Quiles JL. Curcumin ameliorates rabbits's steatohepatitis via respiratory chain, oxidative stress, and TNF-alpha. Free Radic Biol Med 2009; 47: 924-31. [CrossRef]

32. Lenaz G, Battino M, Castelluccio C, Fato R, Cavazzoni M, Rauchova $H$, et al. Studies on the role of ubiquinone in the control of the mitochondrial respiratory chain. Free Radic Res Commun 1990; 8: 317-27. [CrossRef]

33. Yoneda T, Tomofuji T, Kawabata Y, Ekuni D, Azuma T, Kataoka K, et al. Application of coenzyme Q10 for accelerating soft tissue wound healing after tooth extraction in rats. Nutrients 2014; 6: 5756-69. [CrossRef]

34. Nyariki JN, Ochola LA, Jillani NE, Nyamweya NO, Amwayi PE, Yole DS, et al. Oral administration of Coenzyme Q10 protects mice against oxidative stress and neuroinflammation during experimental cerebral malaria. J Parasitol Intern 2019;71:106-20. [CrossRef]

35. Mohamed DI, Khairy E, Shafik Tawfek S, Habib EK, Fetouh MA. Coenzyme Q10 attenuates lung and liver fibrosis via modulation of autophagy in methotrexate treated rat. J Biomed Pharmacother 2019; 109: 892-901. [CrossRef] 


\section{ORIJINAL ÇALIŞMA-ÖZET}

Turk J Surg 2020; 36 (2): 202-208

\section{Cerrahi sonrası yapışıklık önlenmesinde koenzim- $Q$ yaklaşımı}

Ramazan Kuşaslan , Gülçin Ercan', Orhan Ağcaoğlu², Serdar Altınay ${ }^{3}$, Sinan Binboğa ${ }^{1}$, Yüksel Altınel ${ }^{1}$

1 Bağcılar Eğitim ve Araştırma Hastanesi, Genel Cerrahi Kliniği, İstanbul, Türkiye

${ }^{2}$ Koç Üniversitesi Tıp Fakültesi, Genel Cerrahi Anabilim Dalı, İstanbul, Türkiye

${ }^{3}$ Bağcılar Eğitim ve Araştırma Hastanesi, Patoloji Kliniği, İstanbul, Türkiye

\section{ÖZET}

Giriş ve Amaç: Postoperatif intraperitoneal adezyonlar abdominal cerrahide çözülmemiş önemli bir problemdir. Bu çalışmada, koenzim-Q’nun peritoneal yapışıklık gelişimi üzerindeki muhtemel önleyici etkileri araştııılmıştır.

Gereç ve Yöntem: 300-350 g ağırlığında 16 Wistar Hannover erkek sıçan rastgele olarak her biri sekiz sıçandan oluşan iki gruba ayrıldı. Çekum, subserosal kanama gelişene kadar steril bir gazıı bezle aşındırıldı. Çekal aşınmanın karşısındaki bir periton tabakası tamamen disseke edildi. Grup 1 tedavi almadı. Grup $230 \mathrm{mg} / \mathrm{kg}$ koenzim-Q, $2 \mathrm{~mL}$ intraperitoneal olarak enjekte edildi. Tüm sıçanlar postoperatif 21. günde ötenazi edilerek adezyonlar makroskobik olarak skorlandıktan sonra, periton ve bağırsak doku örnekleri histopatolojik incelemeye tabi tutuldu. Antioksidan etkinliği araştırmak için doku ve kan örnekleri biyokimyasal analiz için alındı.

Bulgular: Adezyon skorları kontrol grubu ile koenzim-Q grubu arasında anlamlı farklılık gösterdi $(p=0,001)$. GSH-Px, MDA ve SOD düzeylerinin doku düzeylerine göre, çalışma grupları arasında anlamlı fark yoktu $(p=0,074, p=0,208, p=0,526)$. Plazma GSH-Px ve SOD düzeylerine göre gruplar arasında anlamlı farklılıklar gözlendi $(p=0,002, p=0,001)$, fakat MDA düzeylerinde fark anlamlı düzeyde saptanmadı $(p=0,793)$. Kontrol ve koenzim- $Q$ patolojik skorları arasındaki fark (fibrozis için $p=0,028$; inflamasyon için $p=0,025$ ) istatistiksel olarak anlamlıydı.

Sonuç: Bu çalışma koenzim-Q'nun erken postoperatif adezyonların önlenmesinde potansiyel uygulama olduğunu doğrulamaktadır.

Anahtar Kelimeler: Koenzim-Q, yapışıklık, cerrahi

DOi: $10.5578 /$ turkjsurg.4398 